\title{
Partial Substitution of Cocoa Butter with Processed Shea Butter in Milk Chocolate
}

\author{
Francis Alemawor, Jacob K. Agbenorhevi and Adrian K. Poku \\ Department of Food Science and Technology, Kwame Nkrumah University of Science \& Technology, Kumasi, Ghana
}

\begin{abstract}
Natural cocoa butter is expensive but a major ingredient used for the manufacture of chocolate. The search for alternative cheaper cocoa butter substitute with the similar physical properties, fatty acid and triglyceride content has been proposed. The objective of this study was to evaluate the potential of cheaper and processed (fractionated- or deodorized-) shea butter (FSB or DSB) to partly substitute $5 \%$ and $7.5 \%$ cocoa butter in chocolate production. The proximate composition, microbiological and sensory qualities, as well as estimated cost of the formulated chocolate products were determined and compared with that of the $100 \%$ cocoa butter chocolate as control. Results showed that all the shea butter substituted chocolate samples varying in percentages of incorporation had acceptable proximate composition and microbial quality according to the international standards. Also, there were no significant differences $(P>0.05)$ among all the five samples in terms of flavour, after-taste and texture except for the $7.5 \%$ FSB substituted chocolate which differed significantly $(P<0.05)$ from the other samples in terms of overall acceptability, thus $7.5 \%$ FSB was less preferred by consumers. FSB is cheaper than DSB based on the world market price quotes. Thus the current study recommends the use of FSB for chocolate confectioneries at $5 \%$ substitution rate for cocoa butter could help reduce the cost of chocolate production and increase turnovers.
\end{abstract}

Key words: Shea butter, cocoa butter, chocolate production.

\section{Introduction}

Chocolate is a cocoa (Theobroma cacao L.) bean product that provides valuable nutrients as well as cocoa flavanols having some positive health benefits such as acting as antioxidants protecting against cardiovascular and carcinogenic effects as well as strengthening the natural defenses in case of oxidative stress [1, 2]. Cocoa butter is a major component of chocolate in which non-fat products such as cocoa solids, sugars, proteins (milk proteins), emulsifiers (lecithin), aromas and flavours (vanillin) are dispersed. Cocoa butter is predominantly composed of three triglycerides: palmitic oleic palmitic (POP), palmitic oleic stearic (POSt) and stearic oleic stearic (StOSt). These vary in the range of $60 \%-85 \%$ depending on the origin of the cocoa butter-warmer climates giving rise to higher levels. The other fractions of the fat are mainly stearic oleic oleic (StOO) and palmitic oleic

Corresponding author: Francis Alemawor, Ph.D., research field: food chemistry. E-mail: inthylight96@yahoo.co.uk. oleic (POO). Cocoa butter is solid at room temperature but melts completely around $34-38{ }^{\circ} \mathrm{C}$. The three main triglycerides, however, are known to dominate the polymorphism of cocoa butter [3].

Cocoa butter is an expensive raw material but used in large quantities for the manufacture of chocolate. Attempts have therefore been made to produce substitutes for natural cocoa butter, and numerous substitutes have been suggested. A cocoa butter substitute must be less expensive than cocoa butter and its method of manufacture must be relatively simple. Furthermore, its physical properties, fatty acid and triglyceride content must be comparable with those of cocoa butter [4].

Shea butter is the most affordable and extensively used fat extracted from the kernels of Vitellaria paradoxa (formerly Butyrospermum parkii). The shea tree species are found in several countries across the African savanna zone [6]. The shea butter can be extracted from its kernels by several methods with the two main types. The 
traditional wet and the dry methods as described elsewhere [7-9]. It is very viscous and solid-like at temperatures below $40{ }^{\circ} \mathrm{C}$, but becomes quite fluid at temperatures over $60{ }^{\circ} \mathrm{C}$, the lesser the viscosity, the higher the extraction efficiency [9].

Shea butter is composed of five principal fatty acids: palmitic, stearic, oleic, linoleic and arachidic acid. The composition of the fatty acid is dominated by stearic and oleic acids, which together account for $85 \%-90 \%$ of the fatty acids. The relative proportions of these two fatty acids produces differences in shea butter consistency. The high stearic acid content gives the shea butter its solid consistency, whereas the percentage of oleic acid influences its soft or hard texture [10]. Shea kernels and shea butter are also known to possess high levels of phenolic compounds (with catechins being dominant) as well as tocopherols, with significant regional variation in the content of these antioxidants [6].

Shea butter is used in Africa as a bakery fat and for soap making. It is of great economic importance and a common component of cocoa butter equivalents (CBE) after palm oil [11]. Its fairly high unsaturated fatty acid content means that it needs to be fractionated with the higher melting stearin fraction used in CBE blends [12]. The three major triglycerides of each oil differ in their melting point in the range of $35.2-38.3^{\circ} \mathrm{C}$ for POP to $41.7-43.5^{\circ} \mathrm{C}$ for StOSt. This implies that the more StOSt present in a CBE, the higher its melting point is [13]. Fractionation results higher StOSt level of shea stear in butter and thus increase the SOS level, which makes the fractionated shea oil a good cocoa butter improver for chocolate production.

In Ghana, shea butter is abundant and relatively cheaper but under-utilized. If adequately processed, shea butter can be used as an alternative to cocoa butter. Partly substituting cocoa butter in chocolate with cheaper cocoa butter alternatives like shea butter will reduce cost of production and hence maximize profit and the potential value of shea nut as an economic agricultural produce. The aim of this study, therefore, was to evaluate the potential of processed (deodorized and fractionated) shea butter as a cocoa butter substitute in milk chocolate production as well as to determine the composition, microbiological quality, and consumer acceptability of the shea butter substituted chocolates, using 100\% cocoa butter based chocolate as a standard.

\section{Materials and Methods}

\subsection{Materials}

Shea butter was obtained from the Ghana Nuts Limited, Techiman, Ghana. Cocoa masse was supplied by Cocoa Processing Company Limited (C.P.C.L.), Tema, Ghana.

\subsection{Recipe Formulation}

Five chocolate recipes (Table 1) were formulated with varying amount of processed shea butter/stearin (deodorized/fractionated) to replace cocoa butter by $0 \%, 5 \%$ and $7.5 \%$. Other ingredients were kept constant and the chocolate samples were prepared under strict hygienic conditions.

\subsection{Chocolate Making Process}

A bench top procedure described by the Research \& Development department of the C.P.C.L [14] was followed. Briefly, the ingredients were accurately weighed using an electronic balance according to the recipe and mixed in a saucepan. The mixed ingredients were poured into a fine miller (Royal Duyvis Wiener's W-1-S laboratory ball mill, the Netherlands) and milled for $1 \mathrm{~h}$. A source of steam connected to the miller increased the temperature of the milling ingredients to about $60-70{ }^{\circ} \mathrm{C}$ making milling effective by reducing viscosity. Conching was subsequently carried out for $18 \mathrm{~h}$ in the miller to remove undesirable flavours and to further "polish" the cacao particles, contributing to the smooth taste of the finished chocolate. 
Table 1 Recipes of the individual shea butter substituted and standard chocolates.

\begin{tabular}{llllll}
\hline Ingredients & Recipe 1 & Recipe 2 & Recipe 3 & Recipe 4 & Recipe 5 \\
& $100 \%$ CB $^{1}$ & $5 \%$ DSB $^{2}$ & $7.5 \%$ DSB & $5 \%$ FSB & $7.5 \%$ FSB \\
\hline Cocoa masse & 405.72 & 405.72 & 405.72 & 405.72 & 405.72 \\
${ }^{1}$ CB & 324.00 & 307.80 & 299.70 & 307.80 & 299.70 \\
${ }^{2}$ DSB & Nil & 16.20 & 24.30 & Nil & Nil \\
${ }^{3}$ FSB & Nil & Nil & Nil & 16.20 & 24.30 \\
Sugar & 612.00 & 612.00 & 612.00 & 612.00 & 612.00 \\
Skimmed milk & 450.00 & 450.00 & 450.00 & 450.00 & 450.00 \\
Lecithin (soya) & 7.56 & 7.56 & 7.56 & 7.56 & 7.56 \\
Vanillin & 0.72 & 0.72 & 0.72 & 0.72 & 0.72 \\
Total (g) & 1,800 & 1,800 & 1,800 & 1,800 & 1,800 \\
\hline
\end{tabular}

${ }^{1} \mathrm{CB}=$ cocoa butter; ${ }^{2} \mathrm{DSB}=$ deodorized shea butter; ${ }^{3} \mathrm{FSB}=$ fractionated shea butter (shea stearin).

The chocolate paste was collected in a bowl, and tempered by continuous stirring and monitoring until the temperature attained was $32^{\circ} \mathrm{C}$. The tempered chocolate paste was weighed, $50 \mathrm{~g}$ each, into $50 \mathrm{~g}$ moulds and shaken vigorously on a flat surface until the chocolate paste evenly filled the shape of the mould. The shaking of the mould also removed air bubbles from the chocolate. After moulding, the chocolate in the moulds were put in a refrigerator to cool, harden, brought out to dry, demoulded and finally packaged by wrapping with aluminum foil.

\subsection{Proximate and Microbiological Analyses}

The chocolate samples were analysed for the ash, moisture, fat and sugar contents, total plate count, yeast and mold as well as qualitatively tested for coliform and E. coli, all following standards of the Association of Official Analytical Chemists (AOAC) procedures [15].

\subsection{Sensory Evaluation}

Sensory evaluation was conducted at the Research and Development Department of Cocoa Processing Company Ltd., Tema. Using a cross-sectional sampling approach, questionnaires were given to judges to assess the individual samples. Nine-point hedonic scale sensory test on the chocolate samples was conducted by 20 panelists, assessing the flavour, after-taste, texture and overall acceptability of the 5\% and $7.5 \%$ fractionated shea stear in CBE chocolate and $5 \%$ and $7.5 \%$ deodorized shea butter CBE chocolate type were both compared to the control, i.e., $100 \%$ cocoa butter chocolate. Grading for each sensory parameter had the following ranges: flavour and aftertaste (ranged from none chocolate flavour to strong chocolate flavour), texture (ranged from soft to hard) and finally the overall acceptability using a nine point hedonic scale (i.e., 1-dislike extremely; 2-dislike very much; 3-dislike moderately; 4—dislike slightly; 5-neither like nor dislike; 6-like slightly; 7-like moderately; 8-like very much; 9-like extremely). The results obtained were statistically analyzed.

\subsection{Statistical Analysis}

Data obtained were reported as mean \pm standard deviation. The results obtained were analyzed statistically using SPSS (version 20, IBM SPSS Statistics, US). The mean values of the proximate composition as well as sensory data of the samples were compared using one-way ANOVA followed by LSD post hoc multiple comparisons. Statistical significance tests were performed at $P=0.05$.

\section{Results and Discussion}

Table 2 shows the mean moisture, ash, fat and sugar contents of the individual chocolate samples. All the chocolate samples produced met the International Office of Cocoa and Chocolate/International Sugar Confectionery Manufacturers Association (IOCC/ISCMA) standards [16]. 
Table 2 Mean \pm SD values for proximate composition of individual chocolate samples.

\begin{tabular}{lllllll}
\hline Parameter (\%) & $100 \%$ CB & $5 \%$ DSB & $7.5 \%$ DSB & $5 \%$ FSB & $7.5 \%$ FSB & IOCC/ISCMA standards \\
\hline Moisture & $1.54 \pm 0.12^{\mathrm{a}}$ & $2.21 \pm 0.18^{\mathrm{b}}$ & $2.35 \pm 0.04^{\mathrm{b}}$ & $1.05 \pm 0.01^{\mathrm{c}}$ & $2.17 \pm 0.13^{\mathrm{b}}$ & $2.5 \max$ \\
Ash & $2.24 \pm 0.35^{\mathrm{a}}$ & $1.97 \pm 0.01^{\mathrm{a}}$ & $1.99 \pm 0.00^{\mathrm{a}}$ & $2.47 \pm 0.01^{\mathrm{a}}$ & $1.97 \pm 0.01^{\mathrm{a}}$ & $2.0-3.0$ \\
Fat & $36.45 \pm 0.99^{\mathrm{a}}$ & $34.40 \pm 0.75^{\mathrm{b}}$ & $33.92 \pm 0.09^{\mathrm{b}}$ & $34.18 \pm 0.12^{\mathrm{b}}$ & $33.64 \pm 0.41^{\mathrm{b}}$ & $30.0-35.0$ \\
Sugar (brix) & $22.94 \pm 0.12^{\mathrm{a}}$ & $24.81 \pm 0.03^{\mathrm{b}}$ & $21.58 \pm 0.07^{\mathrm{c}}$ & $20.95 \pm 0.13^{\mathrm{d}}$ & $25.11 \pm 0.02^{\mathrm{e}}$ & $55.0 \max$ \\
\hline
\end{tabular}

Values in the same row with superscripts of different letters are significantly different $(P<0.05)$; IOCC/ISCMA = International Office of Cocoa and Chocolate/International Sugar Confectionery Manufacturers Association.

Table 3 Microbial results on all the individual chocolate samples.

\begin{tabular}{lllll}
\hline Sample & $\begin{array}{l}\text { Total plate count: first } \\
\text { dilution }\left(10^{1} \mathrm{cfu} / \mathrm{mL}\right)\end{array}$ & $\begin{array}{l}\text { Total plate count: second } \\
\text { dilution }\left(10^{2} \mathrm{cfu} / \mathrm{mL}\right)\end{array}$ & Yeast and molds test $(\mathrm{cfu} / \mathrm{mL})$ & Coliform/E. coli \\
\hline $100 \%$ CB & 39 & 0 & 0 & Negative \\
$5 \%$ DSB & 5 & 0 & 0 & Negative \\
$7.5 \%$ DSB & 10 & 1 & 0 & Negative \\
$5 \%$ FSB & 19 & 1 & 0 & Negative \\
$7.5 \%$ FSB & 5 & 0 & 0 & Negative \\
\hline
\end{tabular}

$\mathrm{CB}$ = cocoa butter; DSB = deodorized shea butter; FSB = fractionated shea butter (shea stearin).

High moisture content may result in recrystallization of the sugar on the surface of chocolate and lead to sugar bloom. This condition is favoured when the temperature surrounding chocolate bar falls below dew point, the temperature at which the moisture just begins to condense [5]. Besides, high moisture content, which corresponds with high level of water activity, will decrease the shelf-life of the chocolate [17]. Hence moisture control in chocolate is very critical. Moisture contents also affect the viscosity of chocolate. Low viscous chocolate paste is required for chocolate manufacturing processes with the use of less fat. If moisture content is $0.7 \%$ or below, chocolate viscosity decreases about $25 \%$ as temperature rises from $40{ }^{\circ} \mathrm{C}$ to $55^{\circ} \mathrm{C}$. Above this temperature, there is a slight increase. If moisture content is $1 \%$ or above, viscosity starts to increase as soon as the temperature reaches $45^{\circ} \mathrm{C}$, with a particularly steep incline above $60{ }^{\circ} \mathrm{C}$ [18]. From Table 3, the 5\% fractionated shea butter chocolate with the minimum moisture content of $1.05 \%$ is the most preferred for its rheological properties.

Ash is an indication of the level of inorganic materials present in a sample after the organic portion has been incinerated in a furnace at $670{ }^{\circ} \mathrm{C}$ [18]. Like moisture content determination, ash and mineral content determination of foods is important for nutritional labeling, quality, microbiological stability, nutrition and processing. The primary reason for determination of ash in chocolate confectionery is to indirectly indicate the extent of metals that find their way into products due to wear and tear of processing equipment. Higher ash content may result from metals introduced into products especially from the ball mill and this may be very dangerous to health. However, the values for all the samples are within the acceptable standard range (Table 2).

Fat is a major contributor of chocolate's glossy look, texture, flavour, aroma and taste. Fat level and its particle size influence the viscosity of chocolate. Large particle-sized fat contributes to gritty mouth-feel, but the smaller ones increase the desirable smoothness and glossy appearance in chocolate [19]. Conching helps to decrease chocolate viscosity of large particle size of fat and also aids in meeting the legal fat content [20]. As shown in Table 2, the control (100\% cocoa butter chocolate) recorded $36.45 \%$ fat content, which is slightly above the $35.0 \%$ reference point. This could be due to residual fat contribution from the powdered 
Table 4 Mean \pm SD values of sensory scores for chocolate samples.

\begin{tabular}{|c|c|c|c|c|c|}
\hline Sensory attributes & $100 \%$ CB & $5 \%$ DSB & 7.5\% DSB & $5 \%$ FSB & $7.5 \% \mathrm{FSB}$ \\
\hline Flavour & $4.61 \pm 1.79^{\mathrm{a}}$ & $4.78 \pm 2.07^{\mathrm{a}}$ & $5.78 \pm 1.93^{\mathrm{a}}$ & $4.72 \pm 2.32^{\mathrm{a}}$ & $5.50 \pm 2.36^{\mathrm{a}}$ \\
\hline After-taste & $5.44 \pm 2.53^{\mathrm{a}}$ & $6.00 \pm 1.91^{\mathrm{a}}$ & $5.44 \pm 1.76^{\mathrm{a}}$ & $5.78 \pm 2.24^{\mathrm{a}}$ & $4.72 \pm 2.42^{\mathrm{a}}$ \\
\hline Texture & $5.56 \pm 2.96^{\mathrm{a}}$ & $5.72 \pm 1.87^{\mathrm{a}}$ & $5.06 \pm 2.36^{\mathrm{a}}$ & $4.44 \pm 2.31^{\mathrm{a}}$ & $5.28 \pm 2.59^{\mathrm{a}}$ \\
\hline Overall acceptability & $6.56 \pm 2.12^{\mathrm{a}}$ & $5.83 \pm 1.92^{\mathrm{a}}$ & $5.56 \pm 2.38^{\mathrm{a}}$ & $6.94 \pm 1.92^{\mathrm{a}}$ & $3.61 \pm 2.57^{b}$ \\
\hline
\end{tabular}

Values in the same row with superscripts of the same letter are not significantly different $(P>0.05)$; CB = cocoa butter; DSB = deodorized shea butter; FSB = fractionated shea butter (shea stearin).

skimmed milk that combined with the calculated fat of cocoa butter. Skimmed milk has approximately $4 \%$ milk fat or less, however, inconsistent production of skimmed milk can lead to fat percentages greater than $4 \%$ [21]. However, this has no harmful effect to the consumers.

Sugar was determined as alternate analysis and it serves as sweetener in chocolate. Sugar also provides energy to the consumer but its amount in chocolate is restricted due to possible negative effect such as diabetes risk to consumers.

Results for microbial analyses for the individual chocolate samples are shown in Table 3. Microbial quality analysis is critical in chocolate manufacturing. Total plate count was conducted to determine the total microorganisms on each of the chocolate sample bars. Quantitative test for yeast and mold was conducted since these microbes also contribute in making chocolate samples unsafe. Generally, coliform pathogens are harmful to humans and must be absent from chocolate samples. The results (Table 3) for microbial analysis show that all the chocolate samples were within range per IOCC/ISCMA (1973) standards [16]. It was also observed that the total plate count did not exceed 5,000 cfu and yeast and mold also did not exceed $10 \mathrm{cfu}$. Also, coliform pathogens (including Shigella sp, Salmonella spp., E. coli, etc.) were absent from the samples.

The results from the sensory evaluation are presented in Table 4. For the flavour, after-taste and texture properties assessed, there were no significant differences between the samples $(P>0.05)$. However, the 7.5\% FSB chocolate sample differed significantly $(P<0.05)$ from all the other chocolate samples in terms of the overall acceptability. Thus, on the basis of overall acceptability, the $7.5 \%$ FSB chocolate sample had a lower consumer preference compared with the other chocolate samples. The highest overall acceptability score $(6.94 \pm 1.92)$ observed for the $5 \%$ FSB sample suggests that it would be most preferred by consumers. Additionally the proximate composition and microbial counts for the studied samples were within the international requirements for chocolate.

Exploring the potential of making chocolate cheaper by partly replacing more expensive cocoa butter (the major component in chocolate manufacturing) with processed shea butter is key to this study. Market price estimates per ton of cocoa butter and shea butter are $\$ 12,000-21,000$ and $\$ 6,500-7,500$, respectively [22]. These price quotes suggest some economic benefit of processed shea butter incorporation in chocolate production.

\section{Conclusions}

Incorporation of the processed shea butter was successful since the chocolate bar prepared did not experience any adverse quality effect such as fat bloom which could be due to incompatibility of cocoa and shea butter. From the information on microbiological safety, sensory quality/acceptability and estimated cost of chocolate production, the 5\% fractionated shea butter would be the most cost-effective substitute for cocoa butter in chocolate making in order to increase turnovers and minimize the cost of production.

\section{Acknowledgment}

The research team is grateful to the staff of Research and Development and Quality Assurance Departments of the Cocoa Processing Company Ltd., Ghana, for 
their support.

\section{References}

[1] N.K. Hollenberg, H.H. Schmitz, I. Macdonald, N. Poulter, Cocoa, flavanols and cardiovascular risk, Br. J. Cardiol. 11 (2004) 379-386.

[2] C. Selmi, T.K. Mao, C.L. Keen, H.H. Schmitz, M.E. Gershwin, The anti-inflammatory properties of cocoa flavanols, Journal of Cardiovascular Pharmacology 47 (2006) S163-S171.

[3] N.V. Lovegren, M.S. Gray, R.O. Feuge, Effect of liquid fat on melting point and polymorphic behavior of cocoa butter and a cocoa butter fraction, J. Am. Oil Chem. Soc. 53 (1976) 108-112.

[4] D.J. Pairaud, S. Musso, N.F.C. Bouvron, X.P.X.J.M. Pages, Method of preparing a cocoa butter substitute, US Patent, US4348423, 1982.

[5] G. Talbot, Technology of Coated and Filled Chocolate, Confectionery and Bakery Products, Woodhead Publishing Ltd., Cambridge, UK, 2009, pp. 5-92.

[6] D. Di-Vincenzo, S. Maranz, A. Serraiocco, R. Vito, Z. Weisman, G. Biachi, Regional variation in shea butter lipid and triterpene composition in four African countries, J. Agric. Food Chem. 53 (2005) 7473-7479.

[7] S.A. Mensah, Energy for rural women's enterprises, Ghana, in: S. Misana, G. Karlsson (Eds.), Generating Opportunities: Case Studies on Energy and Women, UNDP, New York, 2001, http://www.undp.org/energy/publications/2001/2001a.htm (accessed May 6, 2014).

[8] C. Carette, M. Malotaux, M. van Leeuwen, M. Tolkamp, Shea Nut and Butter in Ghana: Opportunities and Constraints for Local Processing [Online], 2009, pp. 22-25, http://www.resilience-foundation.nl/docs/shea.pdf (accessed Apr. 29, 2014).

[9] A.M. Olaniyan, K. Oje, Development of model equations for selecting optimum parameters for dry process of shea butter extraction, J. Cereals Oilseeds 2 (2011) 47-56.

[10] J. Alander, Shea Butter with Improved Moisturisation Properties: Personal Care [Online], 2009, pp. 1-3 http://www.aak.com/global/lfc/lfc_sheabutter_with_impr oved_moist_nov09.pdf (accessed May 5, 2014).

[11] S. Maranz, Z. Wiesman, J. Bisgaard, G. Bianchi, Germplasm resources of Vitellaria paradoxa based on variations in fat composition across the species distribution range, Agroforestry Sys. 60 (2004) 71.

[12] M. Lipp, E. Anklam, Review of cocoa butter and alternative fats for use in chocolate-Part A. Compositional data, Food Chem. 62 (1998) 73-97.

[13] D.J. Cebula, K.M. Dilley, The Manufacturing Confectioner, Specialised Publication, New York, USA, 1991, pp. 131-136.

[14] Cocoa Processing Company Limited (C.P.C.L.) Recipe for Chocolate Manufacturing Manual, Tema, Ghana, 2011 http://www.goldentreeghana.com.

[15] P. Cunniff, Official Methods of Analysis of AOAC International (AOAC), 16th ed., AOAC International, Arlington, 1995.

[16] Microbial Examination of Chocolate and Other Cocoa Products, International Office of Cocoa and Chocolate/International Sugar Confectionery Manufacturers Association (IOCC/ISCMA), Brussels, Belgium, 1973.

[17] S.T. Beckett, Industrial Chocolate Manufacture and Use, Wiley Blackwell, York, UK, 2000, pp. 85-103.

[18] J.M. Aeschlimann, S.T. Beckett, International inter-laboratory trials to determine the factors affecting the measurement of chocolate viscosity, J. Texture Stud. 31 (2000) 541-576.

[19] G. Ziegler, R. Hogg, Particle size reduction, in: S.T. Beckett (Ed.), Industrial Chocolate Manufacture and Use, 3rd ed., Blackwell, Oxford, UK, 1999, pp. 65-78.

[20] G. Mongia, G.R. Ziegler, The role of particle size distribution of suspended solids in defining the flow properties of milk chocolate, Int. J. Food Prop. 3 (2000) 137-147.

[21] W.P. Edwards, The Science of Sugar Confectionery, Royal Society of Chemistry, Cambridge, 2000, p. 107.

[22] Soapgoods Inc., Shea Butter-Refined [Online], http://www.soapgoods.com/Butters-c-60.html (accessed May 6, 2014). 